\title{
Persepsi Masyarakat Terhadap Pembangunan Kampus Politeknik Pariwisata Negeri Lombok
}

Abdurrahman ${ }^{1}$, Ramayanto ${ }^{2}$,Ayu Suasmy ${ }^{3}$

1Prodi Administrasi Publik, Universitas Muhammadiyah Mataram, Indonesia

2Prodi Pendidikan ppkn, Universitas Muhammadiyah Mataram, Indonesia

3Prodi Administrasi Publik, Universitas Muhammadiyah Mataram, Indonesia

\section{INFO ARTIKEL}

\section{Riwayat Artikel:}

Diterima: 10-07-2018

Disetujui: 11-03-2018

\section{Kata Kunci:}

1. Presepsi

2. Masyarakat

3. Desa Puyung

4. Poltekpar
Keyword:

1. Perception

2. Society

3. Puyung Village

4. Poltekpar

\section{ABSTRAK}

Abstrak: Persepsi Masyarakat Terhadap Pembangunan Kampus Politeknik Pariwisata Negeri Lombok, peneliti menyimpulkan bahwa pembangunan kampus khususnya di Desa Puyung sangat penting dan perlu dikembangkan agar potensi dan minat warga untuk melanjutkan pendidikan ke jenjang yang lebih tinggi sebagaimana disimpulkan dari hasil wawancara yang menyatakan bahwa mayoritas pendidikan penduduk Desa Puyung adalah tingkat SMA sebanyak 50\%. Pemerintah Daerah dan Desa Puyung harus menyelesaikan masalah yang saat ini sedang dihadapi agar pembangunan kampus berjalan mulus hingga tidak ada lagi masalah apapun.

Adapun metodelogi penelitian yang digunakan adalah metodelogi penelitian deskriptif kualitatif. Hasil penelitian menunjukan bahwa sekitar 58\% masyarakat Desa Puyung menyetujui pembangunan kampus dan sekitar $42 \%$ masyarakat Desa Puyung tidak menyetujui dengan adanya pembangunan kampus Poltekpar Lombok, Pembangunan kampus mempunyai manfaat yang sangat besar untuk masyarakat Desa Puyung. Persepsi masyarakat Desa Puyung yang menyetujui pembangunan kampus tersebut berharap dapat mengurangi jumlah pengangguran di daerah sekitar dan dapat meningkatkan Sumber Daya Manusia (SDM) dalam bidang ekonomi.

\section{Abstract}

The Public Perception of the Construction of Lombok State Tourism Polytechnic Campus, the researchers concluded that the construction of campuses especially in Puyung Village is very important and needs to be developed so that the potential and interest of residents to continue their education to a higher level as concluded from the interviews stated that the majority of education in Puyung Village is a high school level of 50\%. The Regional Government and Puyung Village must solve the problems currently being faced so that the campus construction runs smoothly so that there are no more problems.

The research methodology used is descriptive qualitative research methodology. The results showed that around 58\% of the community of Puyung Village agreed to the construction of the campus and about $42 \%$ of the people of Puyung Village did not approve of the development of the Polytechnic Lombok campus. The campus construction had enormous benefits for the people of Puyung Village. The perception of the community of Puyung Village that approved the construction of the campus hopes to reduce the number of unemployed people in the surrounding area and can increase Human Resources (HR) in the economic field. 


\section{Latar Belakang}

Sejak tahun 2009 pariwisata di Pulau Lombok mulai berkembang dan akhir-akhir ini semakin di kenal oleh para wisatawan, mulai dari para pelancong lokal hingga turis mancanegara. Oleh sebab itu, Pulau Lombok di Nusa Tenggara Barat (NTB) mulai menancapkan diri sebagai destinasi wisata yang wajib di kunjungi.

Salah satu daerah pariwisata di Indonesia yang sangat terkenal setelah Bali adalah Pulau Lombok yang memiliki berbagai potensi wisata, baik wisata bahana maupun wisata budaya dengan pertumbuhan dan perkembangan mengalami kemajuan yang pesat baik dari segi kualitas maupun kuantitas. Berbagai potensi yang dimaksud meliputi potensi alam, potensi manusia. Dengan keunikan dan keindahan alamnya mungkin tidak dapat di temukan di daerah lain di Indonesia.

Sebagai daerah tujuan wisata Pulau Lombok memiliki banyak daya tarik wisata yang menarik untuk dikunjungi baik itu daya tarik wisata budaya, alam dan buatan. Daya tarik wisata tersebut antara lain: pantai, air terjun, kolam renang, Goa Bangkang, gunung rinjani, bukit, taman dan daya tarik wisata lainnya. Seiring dengan perkembangan pariwisata di Lombok kerajinan tenun yang merupakan khas adat dan budaya Lombok hingga kini masih di kembangkan dandi publikasikan secara umum sebagai daya tarik wisata.

Desa Puyung merupakan pusat wisata kedua di Lombok setelah desa Sade. Desa ini terkenal dengan hasil tenun yang memiliki corak yang beragam dengan warna yang cerah. Selain itu, di desa ini jumlah penduduk wanita lebih banyak dari laki-laki. Oleh karena itu, kerajinan tenun lebih banyak dilakukan oleh wanita. Dengan adanya berbagai pariwisata, Pulau Lombok mendapatkan perhatian khusus dari wisatawan. Oleh karena itu, untuk mengembangkan sektor pariwisata Pulau Lombok, pemerintah sudah mengembangkan berbagai hal. Di antaranya adalah infrastuktur jalan untuk mempermudah penjangkauan tempat wisata.

Selain infrastruktur, perkembangan di bidang sumber daya manusia juga berkembang. Banyak masyarakat Pulau Lombok yang mempelajari bahasa asing, apabila ada wisatawan asing yang berkunjung maka bisa dengan mudah di mengerti apa yang sedang dibicarakan, selain belajar bahasa asing masyarakat juga mulai membuka peluang usaha dengan membangun restoran untuk memperkenalkan berbagai macam khas kuliner di Pulau Lombok, dan tidak lupa pula masyarakat juga mulai mempelajari berbagai macam jenis makanan dari berbagai negara, ada pula masyarakat yang membangun penginapan/ perhotelan, hal ini dilakukan oleh masyarakat sekitar untuk membantu perkembangan ekonomi. Tidak hanya belajar di lembaga kursus, masyarakat Puyung memasuki perguruan tinggi khusus yang mempelajari bahasa asing, perhotelan, dan lain sebagainya.Hal tersebut membuat pemerintah mendirikan sebuah sekolah yaitu Politeknik Pariwisata Negeri Lombok di wilayah Kecamatan Jonggat desa Puyung Kabupaten Lombok Tengah. Keberadaan Politeknik Pariwisata (Poltekpar) Negeri Lombok diharapkan akan menjadi salah satu pintu masuk dari kemajuan pesat industri pariwisata NTB. Selain itu, dalam seluruh proses perencanaan pembangunan Poltekpar tersebut harus mencerminkan kekhasan nilainilai agama dan budaya yang dimiliki masyarakat NTB.

Namun dengan adanya pembangunan kampus Politeknik Pariwisata Negeri Lombok menimbulkan berbagai reaksi dukungan dan penolakan dari masyarakat sekitar, dimana setiap reaksi yang bersifat dukunganmaupun penolakan tersebut memiliki dasar argumentasi tersendiri yang dianggap benar oleh masingmasing elemen masyarakat. Berkaitan dengan adanya penolakan tersebut masyarakat melakukan aksi demo dengan bantuan LSM (Lembaga Swadaya Masyarakat) untuk berusaha menggagalkan pembangunan kampus Politeknik Pariwisata Negeri Lombok dengan alasan sengketa tanah, hal tersebut tentunya akan mempengaruhi masyarakat lainnya yang sangat mendukung penuh pembangunan kampus Politeknik Pariwisata Negeri Lombok. Dengan adanya masalah tersebut, tentunya tidak membuat pembangunan kampus dibatalkan, namun pembangunan kampus tetap dilanjutkan hanya saja dampak dari masalah tersebut membuat pembangunan menjadi sedikit terlambat.

Berdasarkan kondisi tersebut dapat di pahami bahwa lebih banyak masyarakat yang mendukung penuh pembangunan kampus Politeknik Pariwisata Negeri Lombok. Tidak 
hanya mendukung pembangunan kampus saja, tetapi masyarakat juga ikut serta dalam melaksanakan istigosah yang diadakan di lokasi pembangunan kampus untuk meresmikan pembangunan kampus Politeknik Pariwisata Negeri Lombok.

Untuk itu, tidak ada alasan bagi masyarakat untuk menolak pelaksanaan pembangunan kampus dan harus didukung penuh. Karena bukan hanya dari sisi ekonomi saja, dalam hal peningkatan kualitas sumber daya manusia (SDM) masyarakat nantinya akan berarti besar karena keberadaan Politeknik Pariwisata Negeri Lombok. Bisa dibayangkan akan berapa banyak warga masyarakat desa Puyung dan sekitarnya yang akan menimba ilmu di kampus tersebut. Dan dengan bekal ilmu tersebut mereka bisa bekerja atau bahkan membuka lapangan kerja baru. Terlebih misi keberadaan Poltekpar Negeri Lombok sangat relevan dengan fokus pemerintah daerah saat ini untuk memajukan dan mengembangkan sektor pariwisata sebagai salah satu pendorong kemajuan daerah.Tinjauan Tinjauan Pustaka

\section{a. Teori Persepsi}

Persepsi merupakan salah satu aspek psikologis yang penting bagi manusia dalam merespon kehadiran berbagai aspek dan gejala disekitarnya. Persepsi mengandung pengertian yang sangat luas, menyangkut intern dan ekstern. Berbagai ahli telah memberikan definisi yang beragam tentang persepsi, walaupun pada prinsipnya mengandung makna yang sama. Menurut Kamus Besar Bahasa Indonesia, persepsi adalah tanggapan (penerimaan) langsung dari sesuatu. Proses seseorang mengetahui beberapa hal melalui Panca inderanya.

Menurut Ruch (1967:300)

persepsi adalah suatu proses tentang petunjuk-petunjuk indera dan pengalaman masa lampau yang relevan di organisasikan untuk memberikan kepada kita gambaran yang terstruktur dan bermakna pada suatu situasi tertentu.

Persepsi manusia terdapat perbedaan sudut pandang dalam penginderaan. Ada yang mempersepsikan sesuatu itu baik atau persepsi yang positif maupun persepsi negatif yang akan mempengaruhi tindakan manusia yang tampak atau nyata.

Bimo Walgito (2004:70) mengungkapkan bahwa persepsi merupakan suatu proses pengorganisasian, penginterpretasian terhadap stimulus yang diterima oleh organisme atau individu sehingga menjadi sesuatu yang berarti, dan merupakan aktivitas yang integrated dalam diri individu.

Dari penjelasan diatas dapat ditarik suatu kesamaan pendapat bahwa persepsi merupakan suatu proses yang dimulai dari penglihatan hingga terbentuk tanggapan yang terjadi dalam diri individu sehingga individu sadar akan segala sesuatu dalam lingkungannya melalui indera-indera yang dimilikinya.

\section{b. Pengertian Masyarakat}

Masyarakat dalam istilah bahasa Inggris adalah society yang berasal dari kata Latin socius yang berarti (kawan). Istilah masyarakat berasal dari kata bahasa Arab syaraka yang berarti (ikut serta dan berpartisipasi). Masyarakat adalah sekumpulan manusia yang saling bergaul, dalam istilah ilmiah adalah saling berinteraksi. Suatu kesatuan manusia dapat mempunyai prasarana melalui wargawarganya dapat saling berinteraksi.

Definisi lain, masyarakat adalah kesatuan hidup manusia yang berinteraksi menurut suatu sistem adat istiadat tertentu yang bersifat kontinyu, dan yang terikat oleh suatu rasa identitas bersama. Kontinuitas merupakan kesatuan masyarakat yang memiliki keempat ciri yaitu: 1) Interaksi antar warga-warganya, 2). Adat istiadat, 3) Kontinuitas waktu, 4) Rasa identitas kuat yang mengikat semua warga (Koentjaraningrat, 2009: 115-118).

Semua warga masyarakat merupakan manusia yang hidup bersama, hidup bersama dapat diartikan sama dengan hidup dalam suatu tatanan pergaulan dan keadaan ini akan tercipta apabila manusia melakukan hubungan, (dalam Soerjono Soekanto 2006: 22), memaparkan bahwa masyarakat adalah suatu sistem dari kebiasaan, tata cara, dari wewenang dan kerja sama antara berbagai kelompok, penggolongan, dan pengawasan tingkah laku serta kebiasaankebiasaan manusia. Masyarakat merupakan suatu bentuk kehidupan bersama untuk jangka waktu yang cukup lama sehingga menghasilkan suatu adat istiadat, (dalam Soerjono Soekanto,2006:22) masyarakat merupakan setiap kelompok manusia yang telah hidup dan bekerja bersama cukup lama, sehingga mereka dapat mengatur diri mereka dan menganggap diri mereka sebagai suatu kesatuan sosial dengan batas-batas yang dirumuskan dengan jelas sedangkan masyarakat menurut Selo Soemardjan (2006:22) adalah orang-orang yang 
hidup bersama yang menghasilkan kebudayaan dan mereka mempunyai kesamaan wilayah, identitas, mempunyai kebiasaan, tradisi, sikap, dan perasaan persatuan yang diikat oleh kesamaan. Menurut Emile Durkheim (1984:11) bahwa masyarakat merupakan suatu kenyataan yang obyektif secara mandiri, bebas dari individu-individu yang merupakan anggotaanggotanya.

Masyarakat sebagai sekumpulan manusia didalamnya ada beberapa unsur yang mencakup.

Masyarakat merupakan manusia yang hidup bersama Bercampur untuk waktu yang cukup lama Mereka sadar bahwa mereka merupakan suatu kesatuan Mereka merupakan suatu sistem hidup bersama.

\section{c. Pembangunan}

Pembangunan dapat diartikan sebagai proses perubahan pada tingkat sistem sosial yang berorientasi pada perbaikan keadaan masyarakat kearah yang lebih baik yang dilakukan oleh pemerintahan dari suatu bangsa dan negara. Menurut Afiffuddin (2010:4), pembangunan adalah membangun masyarakat atau bangsa secara menyeluruh demi mencapai kesejahteraan rakyat. Untuk mencapai hal tersebut ,pembangunan suatu wilayah bukan hanya melakukan program pembangunan yang bergerak dibidang fisik tetapi juga harus bergerak dibidang pembangunan non fisik atau sosial yang meliputi pembangunan manusia, ekonomi, kesehatan, dan pendidikan (Bachtiar Effendi 2002:114).

Penjabaran definisi pembangunan dapat memperhatikan pendapat Adri Patton (2005:6465 )sebagai berikut:

Pembangunan harus merupakan suatu proses, ini di maksudkan bahwa adanya kesinambungan pelaksanaan berdasarkan skala prioritas dan tahapan tertentu.

Pembangunan harus serangkaian usaha yang dilakukan secara sadar, artinya setiap usaha pembangunan harus dilandasi dengan motivasi dasar, sasaran dan tujuan yang jelas dan rasional, atau tidak berdasarkan pemikiran emosional.

Pembangunan dalam perencanaan maupun pelaksanaannya harus sedemikian rupa mengarah pada modernitas, artinya membuahkan perubahan dan hasil bagi masyarakat yang lebih baik dan sejahtera dari keadaan sebelumnya.

Sifat dan watak modernisasi yang akan dicapai itu harus sedemikian rupa bercirikan multi dimensional, artinya harus mencakup semua aspek kehidupan.

Berdasarkan teori-teori yang ada diatas, penulis berpendapat bahwa pembangunan adalah usaha-usaha pengembangan kondisi suatu wilayah yang direncanakan dan dilaksanakan dengan strategi dan mekanisme tertentu oleh pihak yang berwenang (Pemerintah) untuk mencapai kemajuan suatu wilayah yang ditandai dengan adanya suatu perubahan yang meliputi pertumbuhan dan perkembangan masyarakat diwilayah tersebut menuju keadaan yang lebih baik dari segala aspek kehidupan yang meliputi sosial, ekonomi, budaya, politik, agama, dan hukum.

Definisi ini dapat diluaskan dalam skala bangsa dan negara. Keberhasilan pembangunan dalam suatu wilayah sangat ditentukan oleh perencanaan pembangunan, artinya semakin matang suatu perencanaan maka semakin mudah mencapai tujuan pembangunan. Dalam setiap perencanaan pembangunan selalu berdampingan dengan suatu tindakan pelaksanaan atau implementasi dikarenakan suatu perencanaan pembangunan yang baik tanpa implementasi, maka tidak akanberarti karena rencana pembangunan hanya tersimpan rapi dalam arsip kalau tidak mampu di implementasikan. Untuk itu perlu memahami faktor-faktor yang dapat menghambat proses implementasi yang dikemukakan oleh Peters (2003:22) sebagai berikut:

Informasi; kekurangan informasi mengakibatkan adanya gambaran yang kurang tepat terhadap isi dan hasil dari kebijakan yang akan dilaksanakan.

Dukungan; implementasiakan sangat sulit bila pada pelaksanaannya tidak cukup dukungan untuk kebijakan tersebut.

Isi Kebijakan; implementasi kebijakan dikatakan gagal karena masih samarnya isi atau tujuan kebijakan, dan ketidak tepatan atau ketidak tegasan intern ataupun ekstern dari arah kebijakan itu sendiri.

Pembagian Potensi; hal ini terkait mengenai organisasi pelaksana dalam kaitannya dengan diferensiasi tugas dan wewenang. 
Oleh sebab itu, Rippley dan Franklin (2003:21) mengatakan bahwa keberhasilan implementasi harus memperhatikan tiga faktor sebagai berikut:

1. Perspektif kepatuhan (compliance) yang mengukur implementasi dari kepatuhan terhadap kebijakan.

2. Keberhasilan implementasi dapat diukur dari kelancaran rutinitas dan tiadanya persoalan.

3. Implementasi yang berhasil harus mengarah kepada kinerja yang memuaskan semua pihak terutama kelompok penerima manfaat.

\section{Metode Penelitian}

Penelitian ini adalah penelitian kualitatif dengan pendekatan deskriptif. Penelitian kualitatif adalah penelitian yang bermaksud untuk memahami fenomena tentang apa yang dialami oleh subjek penelitian secara holistik, dan dengan cara deskripsi dalam bentuk katakata dan bahasa pada suatu konteks khusus yang alamiah dan dengan memanfaatkan berbagai metode alamiah (Moleong, 2011:6).

Penelitian ini dilaksanakan pada masyarakat desa puyung Kabupaten Lombok Tengah.

Sumber data dalam penelitian ini adalah data primer yang merupakan data yang diperoleh dari hasil pengamatan langsung (observasi) dengan pihak-pihak terkait. Dalam hal ini masyarakat yang ada di sekitar politeknik pariwisata negeri lombok terkait dengan penelitian ini.

Untuk mengumpulkan data yang dibutuhkan dalam penulisan ini maka digunakan pengumpulan data sebagai berikut :

1. Penelitian Lapangan (Field Research)

a. Pengamatan (Observasi)

b. Wawancara (Interview)

Teknik analisa data yang digunakan dalam penelitian ini adalah analisis data kualitatif, mengikuti konsep yang diberikan Miles dan Huberman. Miles dan Huberman dan Saldana (2014), mengemukakan bahwa aktifitas dalam analisis data kualitatif dilakukan secara interaktif dan berlangsung secara terus menerus pada setiap tahapan penelitian sehingga sampai tuntas, dan datanya sampai jenuh. Aktivitas dalam analisis data, yaitu data reduction, data display, data reduction, dan conclusion drawing/verification.

\section{Hasil dan Pembahasan}

\section{a. Persepsi Masyarakat Terhadap Pembangunan Kampus Politeknik Pariwisata Negeri Lombok}

Desa Puyung adalah salah satu daerah yang berada di Kota Praya yang merupakan daerah pedesaan. Adapun latar belakang masyarakat yang berada didesa tersebut adalah bertumpu dari hasil pertanian dan perkebunan, dimana mayoritas mata pencaharian mereka adalah sebagai seorang petani, namun demikian ada juga sebagian masyarakat yang mempunyai mata pencaharian lain misalnya Pegawai Negeri Sipil, TNI, karyawan pabrik, buruh, ojek, dsb.

Selain itu sifat gotong royong dan tolong menolong dalam kehidupan masyarakat yang ada di Desa Puyung sangat kental dan kuat bahkan sudah menjadi prinsip bagi mereka, misalnya dalam aktifitas kehidupan disekitar rumah tangga, kerja bakti, dalam menyiapkan atau melaksanakan pesta dan upacara, serta dalam hal kematian, tolong menolong dengan kaum kerabat dalam hal pekerjaan pertanian, dan masih banyak lagi sikap dan kerelaan menolong dari warga Puyung, mereka rela menolong tanpa berfikir tentang kemungkinan untuk mendapatkan balasan. Desa Puyung adalah Desa yang bersejarah sehingga memiliki adat dan budaya yang kuat, Desa Puyung juga memiliki etika dan tata krama yang harus dijaga dalam bersikap.

Melihat dari latar belakang diatas maka perlu diketahui bagaimana tanggapan atau persepsi mereka terhadap pembangunan kampus Politeknik Pariwisata Negeri Lombok yang dibangun di Desa Puyung. Tentunya banyak sekali argumentasi dari warga tentang persepsi mereka terhadap pembangunan kampus tersebut. Pada paparan data mengenai persepsi masyarakat Desa Puyung terhadap pembangunan kampus Poltekpar mayoritas responden atau $58 \%$ masyarakat memiliki persepsi yang setuju terhadap pembangunan kampus dalam mendukung 
keberadaan kampus Poltekpar karena responden meyakini adanya relevansi antara kampus Poltekpar dan masyarakat yang saling menunjang satu sama lain sehingga meyakini pembangunan kampus dapat meningkatkan Sumber Daya Alam (SDM) masyarakat sekitar.

Namun, $42 \%$ masyarakat tidak setuju karena adanya keinginan atau harapan masyarakat terhadap pemanfaatan lahan tersebut yang bertentangan dengan proyek pembangunan kampus dan kuatnya citra negatif yang tertanam dalam pemikiran masyarakat mengarahkan perhatian masyarakat pada dampak yang bersifat negatif sehingga mengaburkan konsep keterkaitan antara kampus dan masyarakat.

Hasil penelitian mengarah pada satu pemahaman yang sama yaitu untuk mendukung pembangunan kampus Poltekpar sebagai kampus termegah di NTB, maka pembangunan kampus harus menyesuaikan dengan situasi dan kondisi yang ada dikawasan kampus Poltekpar tersebut sehingga dapat mewujudkan sinkronisasi dengan masyarakat sekitar agar dapat saling mendukung satu sama lain.

Pada prinsipnya pembangunan dipandang sebagai kata benda netral yang digunakan untuk menjelaskan proses dan usaha untuk meningkatkan kehidupan ekonomi, politik, budaya, infrastruktur masyarakat, dan sebagainya seperti yang tertera dalam UU No. 28 Tahun 2002 Tentang Bangunan Gedung menimbang :

a. Bahwa pembangunan nasional bertujuan untuk mewujudkan masyarakat adil dan makmur yang merata material dan spiritual berdasarkan Pancasila dan Undang-Undang Dasar 1945

b. Bahwa bangunan gedung penting sebagai tempat manusia melakukan kegiatannya untuk mencapai berbagai sasaran yang menunjang terwujudnya tujuan pembangunan nasional

Pembangunan yang berasumsi bahwa kata pembangunan itu sendiri adalah suatu pendirian atau suatu paham, bahkan merupakan suatu ideologi dan teori serta praktek mengenai perubahan sosial.
Terkait dengan UU No. 28 Tahun 2002 Tentang Bangunan Gedung tersebut Pemprov. NTB berusaha untuk meningkatkan kehidupan ekonomi masyarakat Lombok dengan membangun sebuah kampus Politeknik Pariwisata Negeri Lombok di Desa Puyung Kecamatan Jonggat Kabupaten Lombok Tengah. keberadaan Poltekpar Lombok sangat relevan dengan fokus pemerintah daerah saat ini untuk memajukan dan mengembangkan sektor pariwisata sebagai salah satu pendorong kemajuan daerah. Namun meski mendapat penolakan, proses pembangunan kampus Poltekpar di Desa Puyung, akhirnya dimulai. Ditandai dengan pelaksanaan istighosah dan doa bersama, di lokasi pembangunan. Proses pembangunan kampus Politeknik Pariwisata (Poltekpar) Lombok diperkirakan akan menelan anggaran hingga Rp1,5 triliun. Namun anggaran tersebut tidak sekaligus akan dikeluarkan oleh Pemerintah Pusat, tetapi secara bertahap, sesuai dengan kondisi dan perkembangan kampus. Hal ini akan menjadikan kampus Poltekpar Lombok sebagai kampus termegah di wilayah Indonesia Timur. Bahkan yang terbaik dari sekian banyak kampus Poltekpar yang sudah ada sebelumnya.

Pembangunan kampus Politeknik Pariwisata Negeri Lombok ini ditandai dengan peletakan batu pertama pembangunan kampus oleh Gubernur NTB, Dr. TGH. M. Zainul Majdi, bersama Deputi Pengembangan Pariwisata Kementerian Pariwisata RI, Prof. Dr. H.M. Ahman Sya, pada hari Senin, 2 Oktober 2017. Pembangunan kampus Poltekpar Lombok yang menelan biaya hingga Rp1,5 triliun itu di lakukan secara bertahap. Untuk tahap pertama di tahun 2017 akan di bangun 24 kelas yang dilaksanakan dalam waktu 143 hari atau sampai dengan 31 Desember 2017, dengan total pembiayaan mencapai Rp183 miliar yang bersumber dari Pemerintah Pusat. Untuk tahun 2018, masuk pada tahap kedua, pemerintah kembali menjanjikan mengalokasikan anggaran sebesar Rp180 miliar guna membangun laboratorium, hingga tahun 2019 seluruh fasilitas, sarana dan prasarana pendukung Poltekpar Lombok lengkap seperti ada hotel, restoran, kolam renang, masjid dan taman, hingga penambahan ruang belajar mahasiswa. Tidak hanya itu, 
Pemerintah Provinsi (Pemprov) NTB juga mengalokasikan anggaran Rp2 miliar untuk kebutuhan mebeler dan fasilitas penunjang lainnya.

\section{Simpulan}

Berdasarkan hasil penelitian yang dilakukan di Desa Puyung, Kecamatan Jonggat, Kabupaten Lombok Tengah tentang Persepsi Masyarakat Terhadap Pembangunan Kampus Politeknik Pariwisata Negeri Lombok, peneliti menyimpulkan bahwa pembangunan kampus khususnya di Desa Puyung sangat penting dan perlu dikembangkan agar potensi dan minat warga untuk melanjutkan pendidikan ke jenjang yang lebih tinggi sebagaimana disimpulkan dari hasil wawancara yang menyatakan bahwa mayoritas pendidikan penduduk Desa Puyung adalah tingkat SMA sebanyak 50\%. Pemerintah Daerah dan Desa Puyung harus menyelesaikan masalah yang saat ini sedang dihadapi agar pembangunan kampus berjalan mulus hingga tidak ada lagi masalah apapun. Dengan demikian peneliti dapat menyimpulkan hasil penelitiannya sebagai berikut :

Sekitar 58\% masyarakat Desa Puyung menyetujui pembangunan kampus dan sekitar 42\% masyarakat Desa Puyung tidak menyetujui dengan adanya pembangunan kampus Poltekpar Lombok

Pembangunan kampus mempunyai manfaat yang sangat besar untuk masyarakat Desa Puyung

Persepsi masyarakat Desa Puyung yang menyetujui pembangunan kampus tersebut berharap dapat mengurangi jumlah pengangguran di daerah sekitar dan dapat meningkatkan Sumber Daya Manusia (SDM) dalam bidang ekonomi.

Persepsi masyarakat yang menolak pembangunan kampus Poltekpar dikarenakan masalah sengketa tanah dan kekhawatiran masyarakat sekitar terhadap dampak yang nantinya akan membuat masyarakat tidak harmonis lagi

5. Masyarakat yang menolak dengan alasan sengketa tanah menuntut hak dan kewajiban lahan mereka seluas 41,53 Ha dengan nilai jual sesuai NJOP (Nilai Jual Objek Pajak) sebesar Rp150 juta per are

\section{Saran}

Berdasarkan hasil penelitian tentang pembangunan kampus Poltekpar tentang Persepsi Masyarakat Terhadap Pembangunan Kampus Politeknik Pariwisata (studi kasus di desa Puyung Kecamatan Jonggat Kabupaten Lombok Tengah), banyak informasi yang peneliti peroleh namun informasi tersebut belum sempurna dan membutuhkan penegembangan yang lebih luas lagi sesuai dengan kebutuhan.

Komponen-komponen yang peneliti sarankan diantaranya :

1. Bagi pemerintah Kabupaten Lombok Tengah untuk dapat memperlancar pembangunan kampus Poltekpar yang ada di desa Puyung perlu adanya sosialisasi yang lebih gencar lagi kepada masyarakat yang berargumentasi menolak pembangunan kampus guna untuk mempercepat pembangunan dan supaya pembangunan kampus bisa berjalan dengan baik tanpa ada masalah apapun sehingga dapat memberikan kesadaran dan pemahaman yang lebih mendalam lagi kepada masyarakat tentang penting pembangunan kampus dalam meningkatkan perkembangan pariwisata dan mutu perekonomian masyarakat.

2. Bagi yang akan melakukan penelitian selanjutnya, bila tertarik dengan administrasi/analisis pembangunan kampus yang ada di Kabupaten Lombok Tengah maka peneliti sarankan untuk peneliti meneliti tentang peningkatan kesadaran masyarakat tentang pentingnya partisipasi terhadap pembangunan kampus Politeknik Pariwisata guna untuk meningkatkan perkembangan dunia pariwisata dan meningkatkan perekonomian masyarakat.

\section{Daftar Pustaka}

[1] Dewi, Retno Sari dkk, 2015:"Persepsi Masyarakat Terhadap Lokasi Pembangunan Simpang Lima Kedua Dikecamatan Pedurungan Kota Semarang “. Diunduh melalui https://ejournal2.undip.ac.id; $(01 / 23 / 2018)$

[2] Dharma, Kusuma Kelana. 2011: "Metode Penelitian Kualitatif". Jakarta; Trans Info Media 
[3] Hamzah, Amiruddin. 2015: "Peran masyarakat dalam mewujudkan pariwisata berkelanjutan melalui pengembngan daya tarik wisata kabupaten bulukumba di sulawesi selatan". Diunduh melalui: https://jurnal.poltekpar-makassar.ac.id/. $(01 / 23 / 2018)$

[4] Hariyana, I Kadek dkk, 2015: "Persepsi Masyarakat Terhadap Pengembangan Kawasan Goa Peteng Sebagai Daya Tarik Wisata di Desa Jimbaran Kuta Selatan Kabupaten Badung”. Diunduh melalui: id.portalgaruda.org/index.php (01/23/2018)

[5] Hutagalung, Damoz. 2014: "Persepsi Masyarakat Terhadap Dinamika Pembangunan Kampung Nelayan Belawan”. Diunduh melalui: https://publikasiilmiah.ums.ac.id/. $(01 / 27 / 2018)$

[6] Iriyanto, Setia dkk, 2016: "Dampak Pembangunan Kampus Terpadu Universitas Muhammadiyah Semarang Terhadap Masyarakat Sekitar". Diunduh melalui: repository.usu.ac.id /. (01/27/2018)

[7] Kurnia, Nur Ikhwan. 2017: "Persepsi Masyarakat Kota Samarinda Tentang Rencana Pembangunan Hotel di Kawasan Islamic Centre Provinsi Kalimantan Timur". Diunduh melalui: ejournal.ip.fisipunmul.ac.id/. (01/27/2018)

[8] Oktora, Roni. 2011: "Persepsi Masyarakat Terhadap Pembangunan Jalan Lingkar Utara Kota Solok Provinsi Sumatera Barat". Diunduh melalui: https://ojs.unud.ac.id/. $(01 / 27 / 2018)$

[9] UU Nomor 20 Tahun 2003 tentang Sistem Pendidikan Nasional

[10] UU Republik Indonesia Nomor 28 Tahun 2002 Tentang Bangunan Gedung 